\title{
Problemy współczesnej pedagogiki na łamach czasopisma „Kultura i Edukacja”
}

Celem autorki artykułu jest ukazanie czasopisma „Kultura i Edukacja” jako źródła wiedzy o kierunkach rozwoju i problemach pedagogiki w XX i XXI w. W rozważaniach podjęte zostaną przede wszystkim zagadnienia dotyczące zakresu uwzględniania przez pismo nowych tendencji w rozwoju kultury i edukacji oraz ich wzajemnych relacji. Współczesny świat, transformacje polityczne i społeczne, globalizacja i komputeryzacja stawiają przed pedagogami nowe wyzwania. Warto zatem zapytać o model współczesnego myślenia o edukacji widoczny na łamach kwartalnika „Kultura i Edukacja”.

\section{Ogólna charakterystyka pisma}

Czasopismo „Kultura i Edukacja” powstało w roku 1992 w Toruniu z inicjatywy Wydawnictwa Adam Marszałek, przy współpracy toruńskiego środowiska pedagogicznego. Kwartalnik ten, w założeniach jego twórców, miał trafić do szerokiego grona czytelników, a szczególnie do osób zainteresowanych „przeszłością, obecnym stanem oraz perspektywami rozwoju edukacji jako składowego elementu kultury"1. Redakcja pisma planowała wówczas skupienie się na istotnych zagadnieniach dotyczących relacji pomiędzy kulturą i edukacją, które zbyt

* Dr hab., Pracownia Historii Wychowania, Katedra Podstaw Pedagogiki i Historii Wychowania, Wydział Nauk Pedagogicznych, Uniwersytet Mikołaja Kopernika w Toruniu, 87-100 Toruń, ul. Gagarina 9.

1 Od Redakcji, „Kultura i Edukacja” [dalej: KiE] 1992, nr 1, s. 3. 
rzadko znajdowały odzwierciedlenie na łamach czasopism pedagogicznych. W zamieszczonym w pierwszym numerze pisma słowie wstępnym odnajdujemy informacje dotyczące profilu periodyku, który miał w znacznej mierze uwzględniać dorobek naukowy toruńskiej pedagogiki. $Z$ tych względów teksty tam publikowane mogły reprezentować liczne specjalności, od socjologii i historii wychowania, poprzez pedagogikę społeczną i specjalną, po takie subdyscypliny, jak dydaktyka, antropologia czy innowatyka pedagogiczna².

Twórcy czasopisma otwarcie wyrażali nadzieję na wykorzystanie przez środowiska pedagogiczne nowych możliwości w zakresie wydawania własnych periodyków pozbawionych już ograniczeń związanych ze swobodą wypowiedzi. Zaznaczali, że chociaż „Zawirowania historyczne nie ominęły również polskiego czasopiśmiennictwa pedagogicznego”, wiele pism uległo likwidacji, a ich „Stali czytelnicy [...] odnieśli wrażenie, że nic już nie zdoła zrekompensować poniesionych strat", to nowa sytuacja społeczno-polityczna w znaczącym zakresie umożliwia przełamanie dotychczasowego impasu. Podkreślali, że inicjatywom takim sprzyjają przede wszystkim zjawiska rosnącej autonomii uczelni wyższych, zmian dotyczących funkcjonowania wielu wydawnictw, które muszą uwzględniać mechanizmy rynkowe, demonopolizacji wpływów w środowiskach naukowych oraz likwidacja cenzury.

W ciągu dwudziestu lat istnienia pisma stopniowo ewoluował jego profil i poszerzał się zakres problematyki obecnej na jego łamach. Ukształtowany w wyniku tej ewolucji multidyscyplinarny profil kwartalnika, uwzględniający problematykę pedagogiki, socjologii, kulturoznawstwa, psychologii i filozofii, ale także antropologii, politologii czy społecznych aspektów rozwoju medycyny umożliwia szerokie ujmowanie problemów związanych ze współczesną kulturą i edukacją. W ocenie obecnego redaktora naczelnego Ryszarda Borowicza, „Kultura i Edukacja” od wielu lat realizuje postulat „przekraczania granic dość tradycyjnie zdefiniowanych dyscyplin naukowych”. W związku z tym "nie jest czasopismem ani socjologicznym, ani pedagogicznym... ani - w sensie tożsamości dyscyplinowej - żadnym innym [...]. Funkcjonuje na pograniczu humanistyki oraz nauk społecznych"3.

Zespół redakcyjny „Kultury i Edukacji” tworzyli początkowo, poza wydawcą A. Marszałkiem, głównie pracownicy Instytutu Pedagogiki Uniwersytetu Mikołaja Kopernika w Toruniu. Redaktorem naczelnym pisma był Roman Schulz, a jego współpracownikami m.in. Czesław Kosakowski i Józef Półturzycki, który w roku 1995 został kolejnym redaktorem naczelnym. Wówczas też powołano Radę Naukową czasopisma, w skład której weszli przedstawiciele wielu krajowych ośrodków naukowych. Zespół redakcyjny poszerzył się o kolejnych pracowników Instytutu Pedagogiki UMK - Bronisława Siemienieckiego oraz Eugenię Annę Wesołowską. W roku 1999 na czele Zespołu Redakcyjnego, w składzie: Piotr Petrykowski, Ryszard Borowicz oraz Janusz Mucha, stanął Aleksander Nalaskowski. Wkrótce jednak (od nr 2-3/1999) zastąpił go Wiesław Ciczkowski. Od roku 2000 redaktorem naczelnym pisma jest Ryszard Borowicz. Obecnie w skład Rady Naukowej „Kultury i Edukacji” wchodzą naukowcy z trzech kontynentów: Azji, Ame-

\footnotetext{
2 Tamże.

${ }^{3}$ R. B o r o wi c z, Strategia kwartalnika "Kultura i Edukacja”, KiE 2011, nr 3, s. 172.
} 
ryki Północnej oraz Europy, reprezentujący takie kraje, jak: Chiny, Rosja, Kanada, USA, Czechy, Holandia, Niemcy, Słowacja oraz Węgry.

W gronie autorów tekstów zamieszczanych na łamach pisma początkowo przeważały osoby związane ze środowiskiem toruńskim, pracownicy Uniwersytetu Mikołaja Kopernika. Reprezentowali oni różne wydziały i instytuty tej uczelni - od pedagogicznych po filozoficzne. Jednak już wówczas odnajdujemy tam przedstawicieli innych uczelni, co świadczy o podejmowaniu przez Redakcję współpracy z wieloma krajowymi ośrodkami akademickimi i naukowymi. Jest wśród nich Uniwersytet Warszawski, Uniwersytet Łódzki, Katolicki Uniwersytet Lubelski, Uniwersytet Gdański, Uniwersytet Marii Curie-Skłodowskiej w Lublinie, Uniwersytet im. Adama Mickiewicza w Poznaniu, Uniwersytet Wrocławski, Uniwersytet Szczeciński, Wyższa Szkoła Pedagogiki Specjalnej w Warszawie, Wyższe Szkoły Pedagogiczne w Krakowie, w Rzeszowie oraz w Bydgoszczy. Swoje publikacje zamieszczali w kwartalniku także pracownicy Akademii Obrony Narodowej oraz Polskiej Akademii Nauk (z Instytutu Rozwoju Wsi i Rolnictwa, Instytutu Studiów Politycznych oraz z Instytutu Badań Pedagogicznych).

Współwydawcami pisma byli kolejno: Instytut Studiów Politycznych Polskiej Akademii Nauk (rok 1994), Akademia Obrony Narodowej oraz Wyższa Szkoła Oficerska im. gen. Józefa Bema w Toruniu (rok 1995) i Szkoła Wyższa im. Pawła Włodkowica w Płocku (od roku 1997). Od roku 2010 współwydawcą pisma jest Wyższa Szkoła Gospodarki w Bydgoszczy.

Od trzeciego numeru pismo podjęło współpracę z autorami spoza Polski. Swoje teksty drukowali wówczas profesorowie z Uniwersytetu Vrije w Amsterdamie oraz z Centrum Technologii Społecznej w Białogrodzie. W 1996 r. po raz pierwszy jeden z numerów pisma ukazał się wyłącznie w języku angielskim, co w późniejszym okresie było kontynuowane. Dotychczas ukazało się pięć takich zeszytów (ich wnikliwej analizy i oceny dokonał ostatnio Janusz Mucha ${ }^{4}$ ), a w bieżącym roku po raz pierwszy opublikowano specjalny numer w języku chińskim Spisy treści od pierwszego numeru publikowane są również w języku angielskim oraz niemieckim, czasem po rosyjsku.

Struktura pisma od początku jego istnienia ulegała zmianom. W pierwszym numerze odnajdujemy - oprócz charakterystycznego dla periodyków działu polemik-recenzji i not bibliograficznych - trzy działy tematyczne. Pierwszy z nich dotyczy „Antropologicznych podstaw wychowania”, kolejne zostały zatytułowane „Z historii wychowania i myśli pedagogicznej” oraz „O nowy kształt edukacji”. Redakcja zamieściła felieton Józefa Półturzyckiego pt. Rok '92 (felietony te, podsumowujące dany rok i odwołujące się do ważnych rocznic historycznych, wpisały się w tradycję pisma i były publikowane przez redaktora naczelnego regularnie do roku 1998). W numerze drugim znalazły się nowe działy tematyczne - „Z problemów aksjologii wychowania” oraz „Z problematyki pedagogiki specjalnej”. Redakcja zdecydowała się na dodanie części pisma obejmującej informacje i kronikę. Nie uwzględniono tym razem problematyki antropologicznej.

4 J. M u c ha, „Kultura i Edukacja” - wydania angielskojęzyczne i proces umiędzynarodowienia pisma, KiE 2011, nr 3, s. 183-194. 
Kolejny numer zawierał, oprócz znanej już czytelnikom problematyki pedagogiki specjalnej, takie obszary tematyczne, jak „Z problemów tożsamości pedagogiki współczesnej” oraz „Z kulturowo-społecznych uwarunkowań edukacji”. Wśród innych działów tematycznych, zamieszczanych w kolejnych edycjach pisma, odnajdujemy zagadnienia dotyczące współczesnej filozofii wychowania, statusu naukowego pedagogiki, edukacji obywatelskiej, problemów współczesnego społeczeństwa polskiego i edukacji dorosłych, sztuki i wychowania, edukacji w Europie i na świecie, kulturowo-społecznych uwarunkowań edukacji, komputerów i hipermediów czy relacji pomiędzy kulturą, polityką i wychowaniem.

Znaczące modyfikacje w strukturze „Kultury i Edukacji” nastąpiły w roku 1999, po objęciu funkcji redaktora naczelnego przez Wiesława Ciczkowskiego. Wówczas pojawiły się takie działy, jak: „Na spotkanie XXI w.”, „Krąg podstawowych pytań”, „Zmiana w edukacji i kulturze”, „Wymiary zagrożeń i bezpiecznego rozwoju jednostki ludzkiej” oraz „Historyczne odniesienia” i „Interpretacje sztuki”.

Następna istotna zmiana w tym zakresie nastąpiła w roku 2000. Nowy redaktor Ryszard Borowicz wprowadził stałe elementy struktury pisma, na które składają się artykuły i studia, recenzje i omówienia oraz komunikaty i sprawozdania. Struktura ta obowiązuje do dnia dzisiejszego. Dodatkowo w niektórych numerach pojawił się jeszcze jeden dział - „Komunikaty specjalne”. Zamieszczane w nim teksty poświęcone są często jubileuszom pracy naukowej profesorów ${ }^{5}$ oraz ukazaniu głównych tendencji widocznych w obradach i dyskusjach naukowych na zjazdach pedagogicznych, socjologicznych, kulturoznawczych czy podczas Kongresu Kobiet Polskich. Jednocześnie w ostatnich latach pojawiły się w ramach tego działu ogólne debaty nad problemami współczesnej humanistyki oraz rozważania dotyczące konkretnych publikacjí.

Od roku 2000 brak zatem w piśmie konkretnych działów tematycznych, sygnalizujących zakres podejmowanej w publikowanych tekstach problematyki. Częściowo zadanie to pełnią obecnie właśnie „Komunikaty specjalne”. Jednocześnie pojawiają się pierwsze numery tematyczne pisma. Przykładem jest tutaj zeszyt „Kultury i Edukacji” z roku 2010 (nr 2), poświęcony zagadnieniu ukrytego programu edukacji pedagogów i nauczycieli.

Należy podkreślić, że Redakcja kwartalnika propaguje idee szerszej dyskusji nad najnowszymi wydawnictwami z zakresu humanistyki i nauk społecznych, w ramach działu recenzji, gdzie autorzy prac mogą podejmować polemikę $z$ recenzentami.

W pierwszych numerach pisma nie zamieszczano not o autorach. Jednak stosunkowo szybko, bo już w zeszytach z 1993 r. pojawiły się informacje na ten temat. Początkowo dotyczyły one jedynie stopni i tytułów naukowych (z czego ostatecznie zrezygnowano) oraz miejsca pracy poszczególnych osób. Obecnie informacje te zostały wzbogacone o dokładne adresy instytucji oraz adresy mailo-

${ }^{5}$ Przykładowo: KiE 2007, nr 1 (Doktorat honoris causa prof. Wincentego Okonia; Półwiecze pracy naukowej prof. Andrzeja Piskozuba); KiE 2008, nr 1 (Jubileusz prof. Kazimierza Denka).

${ }^{6}$ KiE 2009 nr 2 (Dyskusja nad książką E. Matyni pt. „Demokracja performatywna”); KiE 2011, nr 2-3 (Cykl publikacji i seminarium poświęcone sytuacji Autora we współczesnej humanistyce).

7 Por. KiE 2007, nr 3; 2008, nr 1, 3. 
we. W ciągu 20 lat istnienia periodyku zmieniała się również jego szata graficzna. Od początku jednak znakiem rozpoznawczym pisma był niebieski kolor okładek.

Pismo dysponuje własną stroną internetową (również w wersji angielskojęzycznej) ${ }^{8}$. Odnajdujemy na niej ogólne informacje na temat czasopisma, Rady Naukowej, Redakcji oraz współpracowników periodyku. Istotną rolę odgrywa archiwum udostępniające spisy treści oraz streszczenia bądź pełne wersje elektroniczne dotychczas opublikowanych zeszytów kwartalnika (ta ostatnia konwencja obowiązuje dla numerów wydawanych od roku 2003).

W związku z dwudziestoletnią obecnością pisma na rynku wydawniczym oraz jego multidyscyplinarnym charakterem warto rozważyć wzbogacenie strony internetowej o szczegółowo opracowaną bibliografię zawartości kwartalnika. Podjęcie takich działań wydaje się zasadne, jeżeli uwzględnimy zarówno liczbę opublikowanych dotychczas na łamach „Kultury i Edukacji” artykułów i recenzji, jak i różnorodność podejmowanych w nich problemów.

\section{Problematyka prezentowana na łamach pisma}

„Kultura i Edukacja” jako pismo, które ukazuje się nieprzerwanie od dwudziestu lat, obchodziła już swoje dwa znaczące jubileusze. Stały się one okazją do podsumowania profilu periodyku, dokonania ocen zamieszczanych w nim tekstów oraz dalszych perspektyw jego rozwoju. Swoją opinię dotyczącą kwartalnika wyraził na jego łamach Zygmunt Kwieciński. W roku 2006 i ponownie w roku 2011 przedstawił dotychczasowe osiągnięcia czasopisma ${ }^{9}$. Zaliczył do nich zarówno wyraźne starania o jego umiędzynarodowienie, jak i dążenie do ukazywania aktualnej sytuacji nauk humanistycznych i społecznych - m.in. poprzez bogaty dział recenzji oraz sprawozdań ze zjazdów, kongresów i sympozjów naukowych. Wśród prezentowanych w periodyku zagadnień Z. Kwieciński wyróżnił kilka istotnych ścieżek tematycznych, do których zaliczył problematykę etyczną, zagadnienia nowych technologii, studia nad młodzieżą, edukacją poza granicami Polski oraz nad płcią kulturową. Jednocześnie podkreślił, że dostrzega dążenia do ukazywania w czasopiśmie „poszukiwania nowych ujęć i odczytań podstawowych kategorii, teorii i metod w socjologii edukacji” oraz „nowatorskie wątki karnawalizacji i kultury śmiechu podejmowane z należytą powagą humanistyczną i badawczą"10.

Jakie zatem problemy współczesnej pedagogiki prezentuje swoim czytelnikom „Kultura i Edukacja”? Na początku tych rozważań należy podkreślić, że na łamach pisma, oprócz studiów teoretycznych, zamieszczanych jest wiele tekstów opartych na wynikach badań empirycznych. Zawierają one interesujące wnioski

${ }^{8} \mathrm{http}: / /$ www.kultura-i-edukacja.pl/strona_glowna.html.

9 Z. Kwie cińs ki, A Review of „Kultura i Edukacja” for the Years 1992-2006 for Adam Marszałek Publishing House in Toruń, KiE 2006, nr 4, s. 7-13; te nże, Recenzja kwartalnika „Kultura i Edukacja" za okres 2006-2011, KiE 2011, nr 3, s. 176-182.

10 Tamże, s. 182. 
dotyczące takich kwestii, jak ogólne kompetencje dziecka ${ }^{11}$, umiejętności wnioskowania ${ }^{12}$ oraz czytania ${ }^{13}$, samoocena studentów ${ }^{14}$, poglądy młodzieży na temat małżeństwa i rodziny ${ }^{15}$, sytuacja dzieci zdolnych w szkole ${ }^{16}$ czy poczucie samotności i alienacji u młodzieży ${ }^{17}$. Publikowane wyniki badań dotyczą nauczycieli - m.in. ich świadomości pedagogicznej, poziomu samorealizacji i aspiracji ${ }^{18}$. Pedagodzy mogą tutaj znaleźć artykuły poświęcone istotnym kwestiom z zakresu metodologii badań ${ }^{19}$.

W pierwszym okresie ukazywania się pisma szeroko uwzględniano w nim problematykę pedagogiki specjalnej. Teksty te obejmowały rozwój jej poszczególnych subdyscyplin oraz biologiczne i medyczne uwarunkowania niepełnosprawności. Podejmowano kwestie kształcenia i wychowania dzieci niepełnosprawnych, ze szczególnym uwzględnieniem integracji oraz właściwego przygotowania nauczycieli dla szkolnictwa specjalnego ${ }^{20}$.

Ważne miejsce na łamach pisma zawsze zajmowały pedagogika porównawcza i edukacja dorosłych. Regularnie prezentowano w nim systemy edukacyjne innych krajów (Francji, Rosji, Grecji, Białorusi, Bułgarii, Niemiec, Portugalii, Szwecji, Belgii, a nawet USA, Australii, Japonii, Izraela czy Chin). Jednocześnie Redakcja publikowała teksty z dziedziny aksjologii i filozofii wychowania, antropologicznych podstaw wychowania oraz edukacji obywatelskiej. Wiele artykułów podejmowało problemy związane z określeniem tożsamości współczesnej pedagogiki oraz nowymi tendencjami rozwoju edukacji. Już na początku lat 90. XX w. na łamach „Kultury i Edukacji” odnajdujemy refleksje dotyczące szkolnictwa nie-

${ }^{11}$ G. Ka pica, Dziecięce kompetencje enigmistyczne synonimem kreatywności i perfekcyjności, KiE 2002, nr 2.

${ }^{12}$ E. Narkiewicz-Nie d bale c, K. Narkiewicz, Umiejętności maturzystów i studentów w zakresie wnioskowania i wyjaśniania, KiE 2001, nr 3-4.

${ }^{13}$ G. Kapica, Elementarna umiejętność czytania we wczesnym dzieciństwie, KiE 2001, nr 1; E. Sz e fle r, Stan kompetencji czytelniczych dotyczących budowy książki dla dzieci u uczniów w młodszym wieku szkolnym, KiE 2003, nr 3-4; G. Ka p i c a, Wybrane aspekty kształtowania umiejętności czytania młodszych uczniów, KiE 2004, nr 2.

${ }^{14} \mathrm{H}$. Kontork ova, Badanie samooceny studentów w zakresie poczucia wewnętrznej odpowiedzialności za ucznia, KiE 2002, nr 1; A. Tu row ska, Znaczenie samooceny w funkcjonowaniu społecznym - na przykładzie młodzieży maturalnej, KiE 2008, nr 2.

${ }_{15}$ T. Biernat, P. Sobierajski, Wyobrażenia młodzieży o małżeństwie i rodzinie (analiza wyników badań pilotażowych), KiE 2002, nr 1.

${ }^{16} \mathrm{G}$. Kapica, Opinie zdolnych uczniów klas początkowych na temat otoczenia oraz własnej osoby, KiE 2001, nr 2.

17 L. J a ku b o w s ka, Współczesne oblicza samotności wśród młodzieży, KiE 2004, nr 4.

${ }^{18} \mathrm{KiE}$ 1996, nr 1.

${ }_{19}$ M.in. KiE 1998, nr 1, 3; M. Malewski, Metody ilościowe i jakościowe w badaniach nad edukacją. Spór o metodologiczną komplementarność, KiE 1997, nr 1-2; W. Sikorski, Dylematy metodologiczne badań nad wzorem osobowościowym uczniów, KiE 1998, nr 1.

${ }^{20}$ Przykładowo KiE 1993, nr 1 (H. Borzyszkowska, O powinnościach pedagoga specjalnego; D. Grzybowska, Samokształcenie $i$ samodoskonalenie nauczycieli szkół specjalnych; A. Hulek, Szkoła masowa wobec uczniów niepełnosprawnych); nr 2 (T. Gałkowski, Autyzm w rodzinie. Ujęcie interdyscyplinarne; A. Giryńs ki, Nastawienia empatyczne a poziom wrażliwości moralnej dzieci lekko upośledzonych umysłowo); nr 3 (Z. S ę k o w s k a, Problemy integracyjnego kształcenia i rewalidacji dzieci niepełnosprawnych); nr 4 (S. S a d o w s k a, Integracja dziecka upośledzonego umysłowo w rodzinie jako pierwszy etap integracji społecznej). 
publicznego ${ }^{21}$, zmian w zakresie kształcenia nauczycieli oraz możliwości wykorzystania w nauczaniu najnowszych technologii.

Nie pominięto także przemian w funkcjonowaniu poszczególnych elementów systemu szkolnego w Polsce, przy czym najwięcej uwagi skupiły na sobie szkoły wyższe. W tekstach podejmowano zagadnienia ogólnej wizji współczesnego uniwersytetu ${ }^{22}$, jego miejsca w systemie kapitalistycznym ${ }^{23}$, sytuacji absolwentów studiów wyższych na rynku pracy ${ }^{24}$, etyki naukowej ${ }^{25}$, dostępu młodzieży wiejskiej do studiów ${ }^{26}$, prób tworzenia uczelni wyższych w Łodzi ${ }^{27}$, rozwoju szkół wyższych niepublicznych ${ }^{28}$ oraz ewaluacji jednostek naukowych ${ }^{29}$. Nie zabrakło jednak również rozważań nad edukacją przedszkolną i wczesnoszkolną ${ }^{30}$.

Autorzy podejmowali kwestie wpływu polityki na ostateczny kształt reform szkolnych ${ }^{31}$ oraz analizowali ich różnorakie aspekty. Przykładowo odnajdujemy na łamach pisma teksty dotyczące szans edukacyjnych dzieci32, stosunku nauczycieli do reform szkolnych ${ }^{33}$, możliwości i zagrożeń rozwoju edukacji w Polsce ${ }^{34}$ oraz wpływu reform na kształcenie nauczycieli ${ }^{35}$. Jednocześnie Redakcja „Kultury i Edukacji” przyjmuje do druku teksty dotyczące roli rodziny w wychowaniu, zmian jej funkcji w świecie współczesnym czy wpływu rodziców na sukcesy szkolne dzieci. Wiele artykułów dotyka problemu rywalizacji, przemocy i agresji wśród dzieci i młodzieży oraz jej różnorodnych uwarunkowań ${ }^{36}$.

„Kultura i Edukacja” ukazuje różne oblicza i aspekty badań nad kulturą oraz jej relacje z pedagogiką, religią, polityką, kapitalizmem, środowiskami lokalnymi czy prawem. Autorzy poszczególnych artykułów podejmują zagadnienia wzorów

${ }^{21}$ M.in. KiE 1997, nr 1-2.

22 K. D e ne k, Ku szkolnictwu wyższemu XXI wieku, KiE 1998, nr 2; K. Wa si le w s ki, Między „młotem” rynku pracy a „kowadłem” uniwersyteckiego konformizmu, czyli uniwersytet na przełomie wieków, KiE 2002, nr 3-4; L. G a w o r, Globalne problemy współczesności a kształcenie uniwersyteckie, KiE 2004, nr 4.

${ }^{23}$ R. B o r o w i c z, Edukacja (wyższa) w budowie „niekompletnego kapitalizmu”, KiE 2005, nr 2.

${ }^{24}$ K. Wa s i l e w s k i, Między „młotem” rynku pracy...; M. O p iło w s k a, Student-gracz jako produkt umasowienia i urynkowienia szkolnictwa wyższego, KiE 2008, nr 1.

${ }_{25}$ A. D ra ba re k, Problem etyki naukowej w poglądach filozofów ze szkoły Iwowsko-warszawskiej-K. Twardowski, KiE 2003, nr 3-4.

${ }^{26}$ K. W a s i e l e w s k i, Droga młodzieży wiejskiej na studia na podstawie badań studentów UMK $w$ Toruniu, KiE 2005, nr 3.

27 A. Klim czak, Próby tworzenia wyższych uczelni w Łodzi, KiE 2009, nr 2.

${ }_{28}$ M.in. KiE 1996, nr 3; 2001, nr 2.

${ }^{29}$ D. A n t o n o w i c z, Ewaluacja jednostek naukowych z perspektywy podatnika, KiE 2010, nr 3.

30 M.in. KiE 1998, nr 2-3.

${ }_{31}$ M. Ślusarczyk, Edukacja tematem wyborczym - polityczne uwarunkowania reform systemów oświaty, KiE 2005, nr 3.

32 R. P a w la k, Wyrównywanie szans edukacyjnych a polska reforma edukacji, KiE 2005 nr 1.

33 KiE 1998, nr 1.

${ }^{34}$ K. De nek, Reforma systemu edukacji szkolnej - oczekiwania i obawy, KiE 2000, nr 1-2;

C. B a n a ch, Szanse i zagrożenia rozwoju edukacji w Polsce, KiE 2005, nr 2.

$35 \mathrm{KiE}$ 1998, nr 4.

${ }^{36}$ K. Sta dnik, Walka młodych kotek. Kultura ukrytej agresji i rywalizacji jako wszechobecny element dziewczęcej codzienności w perspektywie socjologii, KiE 2008, nr 4; K. M u d y ń, K. C a d e r, Emocjonalno-osobowościowe korelaty tendencji agresywnych wśród licealistów, KiE 2011, nr 1. Por. także KiE 1998, nr 3. 
kulturowych w modzie ${ }^{37}$, psychologicznych badań nad kulturą ${ }^{38}$, świata konsump$\mathrm{cjij}^{39}$, postmodernizmu ${ }^{40}$ czy kultury popularnej ${ }^{41}$. Uwzględniają takie kwestie, jak etyczne aspekty transplantologii czy bioetyka.

W dobie globalizacji nie można uniknąć tematów związanych z problemem zachowania własnej tożsamości oraz kształtowania podstaw edukacji międzykulturowej. Na łamach „Kultury i Edukacji” występują zarówno teksty zawierające ogólne rozważania nad procesami globalizacji, jak i prezentujące konkretne problemy. Autorzy podejmują zagadnienia wpływu globalnych przemian cywilizacyjnych na edukację ${ }^{42}$, prób zachowania tradycji i tożsamości regionalnej wobec jednoczącej się Europy ${ }^{43}$ oraz edukacji międzykulturowej na przykładzie m.in. szkół muzułmańskich i romskich ${ }^{44}$.

W periodyku często pojawiają się teksty omawiające problematykę emigracji i migracji ${ }^{45}$. Dotyczą one kwestii tożsamości Polaków na obczyźnie ${ }^{46}$, szkół polskich za granicą ${ }^{47}$, uczniów obcokrajowców w szkołach polskich ${ }^{48}$ oraz możliwości integracji cudzoziemców poprzez edukację ${ }^{49}$. Pojawiły się wyniki badań nad zjawiskami mobilności ludzi nauki oraz studentów ${ }^{50}$.

Wszelkie nowe zjawiska społeczne niosą ze sobą nie tylko szanse, lecz także zagrożenia. Na łamach pisma „Kultura i Edukacja” wiele uwagi poświęcono za-

${ }^{37}$ D. Porczy ń s ki, Dżinsy, skóra i rock'n'roll. Przemiana wzorów kulturowych w modzie, KiE 2011, $\mathrm{nr} 1$.

${ }^{38}$ B. A r cimowicz, K. C a n tare ro, Nowe kierunki w psychologicznych badaniach nad kulturą, KiE 2011, nr 1.

39 Z. Rem is ze ws ka, Świat konsumpcji: przekraczanie własnego „ego”, KiE 2009, nr 1.

40 S. Taboł, Oblicze (post)modernistycznej Europy, tamże.

41 J. N i k o n i u k, The Matrix has you - postmodernistyczny dyskurs o rzeczywistości i symulacji w kulturze popularnej, KiE 2008, nr 2.

${ }^{42}$ A. Ko b y la r ka, Edukacja w kontekście globalnych przemian cywilizacyjnych, KiE 2001, nr 2; A. Męczkowska, Globalizacja jako wyzwanie dla edukacji a problem unifikacji wymagań dydaktycznych nauczyciel, KiE 2002, nr 1.

${ }^{43}$ A. P is kozub, Dziedzictwo tradycji historycznej jako podstawa współczesnej tożsamości regionalnej ziem polskich w jednoczącej się Europie, KiE 2000, nr 1-2.

${ }^{44}$ E. Orłows ka, Klasyczna szkoła arabsko-muzułmańskiej geografii regionalnej, KiE 2000, nr 1-2; J. Cukras - Steląg ow ska, J. Stelą gow ski, W kierunku edukacji międzykulturowej. Parafialna Szkoła Romska w Suwałkach, KiE 2009, nr 1.

${ }^{45}$ K. Zamojski, Czy pojęcie emigracji coś jeszcze wyjaśnia? Szkic fenomenologiczno-krytyczny, KiE 2009, nr 1; J. K u r z ę p a, Konsekwencje socjokulturowe migracji młodego pokolenia Polaków, tamże; A. P o d g ó r s k i, Obraz życia społecznego z perspektywy młodych emigrantów z Polski. Kraj emigracji a kraj własny, KiE 2011, nr 1.

${ }^{46}$ K. Gra b o w s k a - Ga r c z y ń s k a, l’m from Poland - o tożsamości Polaków na obczyźnie, KiE 2009, nr 1.

47 A. Ż u k o w s k i, Szkolnictwo polonijne w Afryce Południowej, KiE 1995, nr 3; A. K u s z t e la k, Szkoła polska poza granicami kraju animatorem integracji społeczności polskiej, KiE 2004, nr 4; te nże, Aksjologiczne problemy szkół przy polskich placówkach dyplomatycznych, KiE 2009, nr 3.

48 J. Kapica-Curzytek, Nauczyciel w szkole jako „culture broker” (pośrednik kulturowy) wobec uczniów obcokrajowców, KiE 2010, nr 1.

${ }^{49}$ R. S i e la c z e k, Edukacja jako narzędzie integracji cudzoziemców, KiE 2008, nr 3.

50 M.in. na łamach KiE 2008, nr 4 (A. J eran, Ludzie nauki w Polsce - między mobilnością a migracją; A. L is, Mobilność studentów i umiędzynarodowienie szkolnictwa wyższego jako czynnik wspomagający konkurencyjność Polski w Unii Europejskiej; B. Stachowiak, Młodzi Polacy na uczelniach europejskich - realne szanse czy tylko marzenia?). 
gadnieniom wykluczenia społecznego. Świadczą o tym teksty prezentujące kulturę ubóstwa i wykluczenia ${ }^{51}$, zagadnienia nieprzystosowania społecznego ${ }^{52}$, selekcji społecznej w edukacji ${ }^{53}$, dostępu młodzieży wiejskiej do edukacji ${ }^{54}$ oraz awansu społecznego dzieci z rodzin robotniczych ${ }^{55}$. Pisano o kwestii rozwoju feminizmu ${ }^{56}$ oraz zjawiskach dyskryminacji kobiet na różnych polach ich aktywności życiowej. Podjęto zagadnienia stosunku współczesnych kobiet do macierzyństwa ${ }^{57}$, roli kobiecego międzygeneracyjnego przekazu kulturowego ${ }^{58}$, edukacji zróżnicowanej i dyskryminacji płciowej w szkole ${ }^{59}$, obrazu kobiecości lansowanego przez pisma kolorowe ${ }^{60}$, przyczyn nieobecności kobiet w sferze publicznej61. Pojawiły się teksty dotyczące edukacji ekologicznej62 oraz seksualnej63, z uwzględnieniem tak trudnych problemów, jak podejście do osób homoseksualnych ${ }^{64}$ czy stosunku nauczycieli do przekazywania uczniom wiedzy na temat HIV i AIDS ${ }^{65}$.

${ }^{51}$ A. Ka rwa c ki, „Kultura biedy” w byłych PGR-ach - geneza problemu i wyzwania dla polityki społecznej, KiE 2002, nr 3-4; A. S kulim o w ska, Poziomy kultury ubóstwa wśród mieszkańców toruńskiego Domu dla Osób Bezdomnych i Najuboższych Stowarzyszenia Monar-Markot, KiE 2004, nr 4; R. Kru szk a, Wykluczenie społeczne - rys interpretacyjny i użyteczność badawcza, KiE 2008, nr 1; W. Duży, Pamiętnik Marcjanny Fornalskiej. Przyczynek do badań nad kulturą ubóstwa, KiE 2009, nr 3.

52 Przykładowo: KiE 1998, nr 2-3; 2000, nr 1-2; 2002, nr 1-2.

53 KiE 1998, nr 2; 2005, nr 3.

${ }^{54}$ B. Jentsch, J. Burnett, Młodzież wiejska w społeczeństwie ryzyka: od kształcenia do zatrudnienia, KiE 2001, nr 2; KiE 2005, nr 3 (K. Wa siele ws ki, Droga młodzieży wiejskiej na studia na podstawie badań studentów UMK w Toruniu, B. B o ra w s k a, Awans edukacyjny młodzieży wiejskiej w okresie zmiany systemowej (na przykładzie dwóch powiatów województwa podlaskiego); M. Hoły, Wpływ położenia gminy na proces edukacji młodzieży wiejskiej z obszaru Małopolski); A. Woj t e wi c z, Czy prowincjonalne szkoły zdolne są do optymalizacji społecznej wartości dzieci rozważania nad kondycją szkół wiejskich w kontekście teorii Jamesa S. Colemana, KiE 2006, nr 2-3.

55 J. Głu sze k, Specyfika socjalizacyjna rodziny robotniczej z perspektywy pytania o awans społeczny, KiE 2007, nr 1.

${ }^{56}$ I. B u kraba-Ry Is ka, Kwestia kobieca: od feminizmu do mulieryzmu, KiE 2009, nr 3. Por. KiE 2001, nr 2.

${ }^{57}$ U. K u si o, Współczesna kobieta wobec macierzyństwa, KiE 2004, nr 4.

${ }^{58}$ B. O w e r c z u k, Obraz kobiety w międzygeneracyjnym przekazie kulturowym: Babka - Matka - Córka, KiE 2007, nr 4.

${ }^{59} \mathrm{~K}$. N a g ó r n y, Kobiety do szydełkowania, mężczyźni do matematyki. O niejasnościach wokół edukacji zróżnicowanej, KiE 2008, nr 3; M. C h o m c z y ń s k a - R u b a c h a, Dyskryminacja w szkole ze względu na płeć w perspektywie krytycznej socjologii edukacji, KiE 2011, nr 1.

60 D. Z a wors ka-Nik on i u k, Wieloznaczność kobiecości unowocześnianej i wyimaginowanej w magazynach luksusowych dla kobiet (na przykładzie prezentacji ciała), KiE 2008, nr 1.

${ }^{61}$ N. K r z yża no w sk a, „Czego Jaś-ia się nie nauczy, tego Jan-ina nie będzie umiat-a”, czyli o przyczynach (nie)obecności kobiet w sferze publicznej, KiE 2008, nr 4.

${ }_{62}$ M. Grudzińska-Jurczak, A. Bartosiewicz i in., Świadomość i wiedza na temat odpadów komunalnych mieszkańców województw małopolskiego i podkarpackiego, KiE 2002, nr 1; K. Kopczyńs ki, Duchowe, społeczne i terapeutyczne walory wychowania proekologicznego, KiE 2010, nr 3. Por. KiE 1998, nr 2.

${ }^{63}$ E. Wejbert-Wąsiewicz, J. Stanisz, Sto lat oświaty seksualnej w Polsce. Ideologia i polityka a potrzeby społeczne, KiE 2009, nr 2.

${ }^{64}$ P. S kuza, O jednym nieobecnym dyskursie - homoseksualizm w pedagogice, KiE 2004, nr 4; t e nż e, O pedagogikę odmienności seksualnej (teoria queer), KiE 2006, nr 2-3.

65 J. W o j c i e c h o w s ka, Ocena przygotowania nauczycieli szkół średnich Gdańska do prowadzenia zajęć na temat społecznych aspektów HIV/AIDS, KiE 2010, nr 4. 
Dużo miejsca poświęcono rozwojowi nowoczesnych technologii informacyjnych oraz wynikających z nich możliwości i zagrożeń. Na łamach pisma odnajdujemy teksty poświęcone możliwościom wykorzystania technik komputerowych w edukacji66, wpływowi rewolucji informatycznej na proces alfabetyzacji ${ }^{67}$ oraz ukształtowanie się społeczeństwa informacyjnego i jego relacji ze światem polityki68 $^{68}$. Omawiane są zagadnienia cyberprzestrzeni, cyberkultury oraz związanego z nimi rozwoju mediów, kompetencji informatycznych nauczycieli, znaczenia Internetu dla rozwoju różnorakich ruchów religijnych oraz społeczności lokalnych ${ }^{69}$. Omawiano zagadnienia trudne, obejmujące zagrożenia i możliwości wykorzystania gier komputerowych $w$ edukacji ${ }^{70}$ oraz nauczania wirtualnego ${ }^{71}$, a także problem wykorzystywania seksualnego dzieci i młodzieży za pośrednictwem Internetu ${ }^{72}$ oraz skutków rozwoju społeczności internetowych ${ }^{73}$.

W dobie nieograniczonego dostępu dzieci do mediów i technologii informacyjnych niepokój pedagogów budzi niski poziom czytelnictwa. Odzwierciedlenie tego niepokoju odnajdujemy w zamieszczanych w kwartalniku tekstach dotyczących edukacji literackiej. Mają one różnoraki charakter - od ogólnych rozważań nad znaczeniem kultury literackiej w pracy pedagogicznej i edukacyjnej funkcji literatury dziecięcej i młodzieżowej ${ }^{74}$ po próby zaprezentowania możliwości wykorzystania konkretnych tekstów z literatury dziecięcej i młodzieżowej w dydaktyce szkolnej ${ }^{75}$ - jest wśród tych propozycji zarówno Harry Potter Joanne Kathleen Rowling, jak i Malutka Czarownica Otfrieda Preusslera. Pojawiają się rozważania nad wizerunkiem dziecka i dzieciństwa w baśniach, w poezji, w kołysankach, literaturze fantasy, a obok nich - wyniki badań nad rozpoznawalnością cytatów literackich przez studentów czy rozważania nad znaczeniem ilustracji w literaturze dziecięcej ${ }^{76}$.

${ }^{66}$ B. Siemieniecki, Nowe możliwości stosowania techniki komputerowej w edukacji, KiE 1992, nr 1; tenże, Cele kształcenia a komputerowe wspomaganie procesu dydaktycznego, KiE 1992, nr 2.

67 G. Kapica, Wybrane problemy...

68 P. Pszczółkowski, Pytanie o model przywódcy politycznego na tle kształtującego się społeczeństwa informatycznego, KiE 2002, nr 1.

69 Teksty takie odnajdujemy na łamach następujących numerów tego pisma: 2002, nr 3-4; 2004, nr 1; 2005, nr 2; 2010, nr 4.

70 S. Ta b oł, Niebezpieczne gry komputerowe, KiE 2006, nr 1.

71 M. N a w ojczy k, A. C h r zą s z cz, Wirtualne nauczanie. Przekraczanie kulturowych i technologicznych barier. Przypadek icamp, KiE 2008, nr 1.

${ }^{72}$ A. G r a b o w s k a, Praktyczne oraz prawne rozważania wokół problemu wykorzystywania seksualnego dzieci, w tym również za pośrednictwem Internetu i nowoczesnych technologii, KiE 2010 , nr 4.

${ }^{73}$ A. N owa kows ka, Społeczności internetowe - realny czy nierealny świat społeczny, KiE 2007, $\mathrm{nr} 4$.

74 KiE 2002, nr 2; 2004, nr 3; 2006, nr 2-3; 2007, nr 2.

75 Przykładowo: KiE 1997, nr 1-2; 2002, nr 2; 2005, nr 4.

76 B. I wi cka, Droga, wędrówka, wędrowiec. Poetyka literatury fantasy, KiE 2000, nr 1-2; Z. O żó g, Słuchamy śpiewu drzew i nie boimy się marzyć. Dziecko w poetyckiej przestrzeni wierszy lat osiemdziesiątych i dziewięćdziesiątych, KiE 2001, nr 2; KiE 2004, nr 4 (M. O s t a s z, O kulturze dziecięcej. Studium na przykładzie wiersza-kołysanki, E. Sze fle r, Kultura literacka dzieci. Analiza książki B. Reuter „Hodder ocala świat”); I. S y m o n o w i c - J a bło ń s k a, Baśniowość w kulturze popularnej jako wyzwanie edukacyjne?, KiE 2005, nr 4; M. Kra s u s k a - B e ti u k, Cytaty literackie w świadomości studentów pedagogiki. Relacja z badań, KiE 2006, nr 1; E. Szefle r, Wzbogacanie wiedzy dzieci o budowie książki na podstawie ilustracji śródtekstowych, KiE 2007, nr 4. 
Wprowadzanie uczniów w kulturę dokonuje się nie tylko za pomocą książek, lecz także filmu, teatru, muzyki czy działalności domów kultury. Na łamach „Kultury i Edukacji” znajdują się teksty dotyczące kina ${ }^{77}$, edukacji i kultury filmowej ${ }^{78}$, roli sztuki $w$ wychowaniu ${ }^{79}$, teatru dla osób niepełnosprawnych ${ }^{80}$ oraz edukacji i kultury muzycznej ${ }^{81}$, roli słuchowisk radiowych ${ }^{82}$ oraz funkcji domów kultury ${ }^{83}$.

Kultura obejmuje zjawiska współczesne, tradycję i dorobek poprzednich pokoleń. Dlatego też w analizowanym czasopiśmie nie brak tekstów prezentujących zagadnienia z zakresu historii, historii wychowania oraz dziejów myśli pedagogicznej ${ }^{84}$. Dotyczą one m.in. ideologii wychowania narodowego ${ }^{85}$, sytuacji oświaty i nauczycieli w okresie II wojny światowej oraz w czasach stalinowskich ${ }^{86}$, rozwoju

77 M. Sokołows ki, Kino i sacrum, KiE 2002, nr 2.

78 E. Konie czna, Rola edukacji filmowej w złożonym procesie wychowania, KiE 1998, nr 1; t a ż, Od edukacji filmowej do edukacji kulturalnej- szkic o roli filmu w edukacji kulturalnej dzieci i młodzieży, KiE 2004, nr 1; E. Kon i e czna, B. D zi a d zi a, Film jako wehikuł kultury. Uwarunkowania uczestnictwa w kulturze filmowej, KiE 2004, nr 2.

79 H. D e p ta, O wartości wychowawczej sztuki uwagi polemiczne, przekorne i (częściowo) bluźniercze, KiE 1994, nr 1; B. B o n na, Rola sztuki w życiu człowieka, KiE 2003, nr 3-4.

$80 \mathrm{~J}$. Michałowska, Praktykowanie obecności - strategie budowania relacji widz - aktor w teatrze osób chorych i niepełnosprawnych psychicznie, KiE 2011, nr 1.

${ }^{81}$ E. Szubertows ka, Szkoła jako źródło kultury muzycznej młodzieży, KiE 2003, nr 3-4; t a ż, Stosunek do przedmiotu „muzyka” a kompetencje muzyczne młodzieży, KiE 2004, nr 4.

${ }^{82}$ K. Albińska, Słuchowisko w erze „nowego radia”. O współczesnym sposobie istnienia teatru audialnego i jego statusie, KiE 2011, nr 1.

83 I. To m a la, Funkcjonowanie domu kultury w mieście gminnym, KiE 2009, nr 1.

${ }^{84}$ Przykładowo: KiE 1994, nr 2-3 (O. S u c h o m l i ń s k a, Związki Celestyna Freineta z Ukrainą; E. A. W e s oło w s k a, Wartości i cele człowieka według Mariana Zdziechowskiego; A. C h o d u b s k i, O zasługach Aleksandra Makowiejskiego dla rozwoju nauki i oświaty w Azerbejdżanie; W. Kołod z i e j, Oświata w Okręgu Szkolnym Krakowskim w latach 1945-1948); J. K w i e k, Związek Harcerstwa Polskiego w latach 1944-1950: ciągłość czy zmiana?, KiE 1995, nr 3; KiE 1996, nr 1 (A. P i s k o z u b, Od propagandy sukcesu do sukcesu propagandy. Ewolucja polskiej myśli morskiej w ciągu XX wieku; L. J. We I k e r, Falerystyka walcząca); E. A. W e s oł o w s k a, Wacław Worowski-rosyjska myśl krytyczna na rozdrożu, KiE 1996, nr 2; KiE 1997, nr 1-2 (R. J a d c za k, Helena Słoniewska: wierna pamięci i wskazaniom programowym Kazimierza Twardowskiego, B. B a raniak, Poglądy i działalność edukacyjna Wandy Haberkantówny na tle historii); KiE 1997, nr 3-4 (W. C i c z k o w s k i, Aleksandra Kamińskiego droga stawania się wychowawcą i uczonym, M. B y blu k, Rosyjski dialog edukacyjny z przeszłością - własną i obcą; A. P is kozu b, Dzieło życia w maszynopisie); D. C i c h e c k a, Zenon Parvi - nieznany brat Stanisława Wyspiańskiego, KiE 1998, nr 1; J. D ą b r o w s k a, Zapomniane ogniwo kultury polskiej - działalność edytorska 2 Korpusu Polskiego, KiE 2007, nr 1; J. Orzeł, Edukacja szlachcica - ideały i postulaty w staropolskim piśmiennictwie pedagogicznym, KiE 2011, nr 2.

${ }^{85}$ W. W oj d yło, Naród - charakter narodowy - wychowanie narodowe w koncepcjach społeczno-politycznych Stanisława Grabskiego w latach 1918-1939, KiE 1993, nr 4; t e n ż e, Wychowanie jako forma działania politycznego w koncepcjach obozu narodowego przed I wojną światową, KiE 1995, nr 3; S. Ki I i a n, Wokół ideału edukacyjnego obozu narodowego w latach 1926-1939, KiE 1997, nr 3-4.

${ }^{86} \mathrm{KiE}$ 1992, nr 1 (A. Wojta s, Wpływ środowisk katolickich na politykę oświatową Rządu RP w latach II wojny światowej; W. T h e is s, Szkoła i nauczyciel w okresie stalinowskim. Pytania i obszary poszukiwań); A. W oj ta s, O potrzebie badań nad procesami wychowania w okresie stalinowskim, KiE 1994, nr 4; M. Strzele cki, Wychowanie samorządowe w koncepcjach i działalności opozycji parlamentarnej w latach 1945-1947, KiE 1995, nr 2; W. The is s, Dzieci i młodzież - przeciwnicy stalinowskiego reżimu, KiE 1996, nr 1; W. Woj d yło, Historia zniewolenia. Edukacja historyczna w stalinizmie, KiE 1998, nr 4. 
polskich czasopism pedagogicznych ${ }^{87}$, działalności różnorodnych towarzystw opiekuńczych i naukowych ${ }^{88}$ czy rozwoju pedagogiki akademickiej ${ }^{89}$.

„Kultura i Edukacja” publikowała również teksty odnoszące się do ideału wychowawczego Narodowej Demokracji ${ }^{90}$ oraz jej stosunku do mniejszości narodowych ${ }^{91}$, koncepcji oświatowo-wychowawczych legalnej opozycji politycznej w Polsce w okresie powojennym ${ }^{92}$, wojskowej myśli wychowawczejej ${ }^{93}$ oraz praktycznej organizacji wychowania wojskowego ${ }^{94}$. Uwzględniono szkice dotyczące studentów Uniwersytetu Jagiellońskiego z XIX i XX w. i ich tożsamości narodowej ${ }^{95}$. Pismo przybliża też sylwetki osób zaangażowanych w rozwój oświaty m.in. Tadeusza Łopuszańskiego ${ }^{96}$, Wacława Tokarza, Janusza Jędrzejewicza, Mariana Kukiela ${ }^{97}$ oraz Ludwika Jaxy-Bykowskiego ${ }^{98}$. Jednocześnie wielu autorów odwoływało się w swoich tekstach do koncepcji filozoficznych i pedagogicznych Cycerona ${ }^{99}$, Stanisława Staszica ${ }^{100}$, Bronisława Trentowskiego ${ }^{101}$, Heleny Radlińskiej i Jacka Woronieckiego ${ }^{102}$, Stefana Baleya ${ }^{103}$, Józefa Gołuchowskiego ${ }^{104}$ czy Stefana Szumana ${ }^{105}$.

87 Por. KiE 1992, nr 2.

${ }^{8}$ W. The is s, Pomorskie Towarzystwo Opieki nad Dziećmi (1918-1948), KiE 1994, nr 4.

89 W. S z u la ki e w i c z, Powołanie katedr pedagogiki w Uniwersytecie Stefana Batorego i Uniwersytecie Jana Kazimierza, KiE 2003, nr 3-4.

90 E. P a r u z e I, „Charakter narodowy” społeczeństwa polskiego według Romana Dmowskiego, KiE 1993, nr 2.

91 G. Ra do m ski, Narodowa Demokracja wobec przejawów aktywności kulturalnej mniejszości narodowych w Drugiej Rzeczypospolitej, KiE 2001, nr 2.

92 M. S t rze l e c k i, Koncepcje oświatowo-wychowawcze legalnej opozycji politycznej w latach 1945-1947, KiE 1993, nr 2.

93 B. Ru d n i ck i, Wojskowa myśl wychowawcza w okresie staropolskim (X-XVIII w.), cz. I, KiE 1996, nr 3; cz. II, 1996, nr 4; cz. III, Koncepcje wychowania w Szkole Rycerskiej, 1997, nr 1-2.

${ }_{94}$ R. To m a s z e w s k i, Spór o oficera polskiego jako historyczny determinant celów kształcenia i wychowania w szkolnictwie wojskowym, KiE 1995, nr 1; t e nże, Szkic do dziejów Wyższej Szkoły Wojennej w Warszawie 1919-1939, KiE 1997, nr 3-4; t e n ż e, Szkic z dziejów szkolnictwa wojskowego w Polsce, KiE 2002, nr 3-4.

95 M. M. Ty tk o, Corpus studiosorum Universitatis lagellonicae. Zmiany tożsamości narodowościowej studentów UJ w latach 1850-1918, KiE 2009, nr 2.

96 R. L u bań s k a, Tadeusz Łopuszański 1874-1955, KiE 2004, nr 2.

97 R. To m a s ze w s k i, Wacław Tokarz - Janusz Jędrzejewicz - Marian Kukiel (między oświatą a polityką), KiE 2007, $\mathrm{nr} 1$.

98 J. Hell wi g, Ludwik Jaxa-Bykowski (1881-1948) profesor Uniwersytetu Poznańskiego i kierownik Katedry Pedagogiki, KiE 1996, nr 2.

99 W. P o p i a k, Cyceron, nauczyciel-wychowawca Rzymian, KiE 1994, nr 4; D. Ka rn o w s k a, Cycero i jego myśl społeczna odczytana w dobie transformacji systemowej w Polsce. O trzech przesłaniach Cycerona, KiE 1999, nr 1.

$100 \mathrm{KiE} 1994, \mathrm{nr} 2-3$.

101 S. S z t o b ry n, Badania nad pedagogiką B. Trentowskiego, KiE 1992, nr 2; K. M. Woli ń ski, O wychowaniu człowieka obywatela na tle koncepcji pedagogicznych Bronisława Ferdynanda Trentowskiego, Pierra Bourdieau i Ivana Illicha, KiE 2000, nr 3-4.

102 J. Ja błoń s k a, Autorytet wychowawcy w koncepcjach pedagogicznych Heleny Radlińskiej i o. Jacka Woronieckiego OP, KiE 1996, nr 4.

103 R. J a d c z a k, Z międzywojennej działalności Stefana Baleya (1885-1952) na polu psychologii i pedagogiki, KiE 1995, nr 1.

104 E. Wa s i l e w s k i, Filozofia ducha narodu Józefa Wojciecha Gołuchowskiego, KiE 1998, nr 4.

105 M. M. Ty t k o, Teatr dla dzieci i młodzieży w koncepcji Stefana Szumana, KiE 2011, nr 2. 
„Kultura i Edukacja” ma też pewne osiągnięcia w zakresie publikowania materiałów źródłowych do dziejów oświaty. Na łamach pisma odnajdujemy bowiem m.in. korespondencję Kazimierza Twardowskiego z Anielą Szycówną ${ }^{106}$ oraz dokumenty z archiwów Iwowskich, ukazujące działalność i drogę naukową cenionych historyków wychowania - Stanisława Łempickiego i Łukasza Kurdybachy ${ }^{107}$. Czasem teksty dotyczące kwestii historycznych odnajdujemy również w innych działach pisma ${ }^{108}$.

Jak wynika z przeprowadzonych w prezentowanym szkicu analiz, „Kultura i Edukacja" prezentuje swoim czytelnikom różnorodne aspekty rozwoju współczesnej pedagogiki. Uwzględnia zarówno jej klasyczne subdyscypliny, jak i najnowsze interdyscyplinarne kierunki poszukiwań badawczych i to nie tylko w ich aspekcie teoretycznym, lecz także empirycznym. Teksty zamieszczone na łamach pisma odzwierciedlają różnorodne problemy, z którymi pedagogika zmagała się w ciągu ostatnich dwudziestu lat. Jednocześnie widoczne w poszczególnych artykułach nawiązania do dotychczasowego dorobku i tradycji oświatowych, filozoficznych czy kulturowych poprzednich pokoleń świadczą o tym, że współczesna pedagogika uwzględnia także „historyczne odniesienia”.

\section{Uwagi końcowe}

„Kultura i Edukacja” jest obecnie pismem o ugruntowanej pozycji na rynku czasopism naukowych. Świadczy o tym dwudziestoletnia tradycja periodyku oraz uwzględnienie go na tzw. liście filadelfijskiej. W latach 1992-2011 ewoluował zarówno skład Rady Redakcyjnej, jak i struktura kwartalnika. Jednocześnie jednak analiza tematyki zamieszczanych na jego łamach artykułów, studiów, relacji i komunikatów wskazuje na nieprzemijającą aktualność wielu wyzwań, jakie stanęły przed polską pedagogiką po roku 1989. Na łamach pisma odnaleźć można nawiązania do głównych tendencji widocznych w rozwoju społeczeństw, kultury i edukacji ostatniego dwudziestolecia, nie tylko w perspektywie Polski, lecz także Europy i świata.

106 R. Ja d c za k, Trzy listy Anieli Szycówny do Kazimierza Twardowskiego, KiE 1992, nr 1.

107 W. W o j d yło, M. S t r z e l e c k i (Droga Stanisława Łempickiego do katedry uniwersyteckiej, KiE 1995, nr 2; Działalność naukowa Łukasza Kurdybachy w świetle dokumentów Uniwersytetu Jana Kazimierza we Lwowie, KiE 1996 nr 2).

108 Przykładowo w KiE 1994, nr 2-3, w dziale „Edukacja obywatelska”, zamieszczono artykuły o historycznym znaczeniu patriotyzmu oraz o stworzonym przez S. Staszica ideale obywatela, natomiast w roku 1995, nr 2 dział zatytułowany „Kulturalno-społeczne uwarunkowania edukacji” zawierał teksty dotyczące Janusza Korczaka, pedagogów radzieckich oraz bibliografię prac Aleksandra Lewina. 